\title{
ANALISIS DATA HASIL KEUNTUNGAN MENGGUNAKAN SOFTWARE RAPIDMINER
}

\author{
Rika Nofitri, Novica Irawati \\ Program Studi Sistem Komputer, STMIK Royal Kisaran \\ email: nofitririka15@gmail.com
}

\begin{abstract}
The application of information technology is currently growing so rapidly. One of them is the application of technology that can be applied in the industrial world, namely to evaluate the company's performance. Evaluation is a necessity for companies to move forward and develop in facing business competition. One method of evaluating that can be used objectively is extracting information through a stored database. This study intends to analyze the factors that affect profit outcomes based on profit-based data. The data will be analyzed using method Bayes. Through this method will get a pattern that affects profits. However, it is not easy to analyze data with this method because of the large amount of data that will cost a lot of time and time. So to simplify the analysis, researchers use tools in analyzing the data the results of the benefits of rapidminer software. Based on the results of the analysis carried out, rapidminer software can help and make it easier to produce probabilities to be predicted. The results of this study are from the set test conducted, the prediction of profit results can be ascertained to be achieved and the possibility of certainty is reached $0.59 \%$ and the possibility of not reaching $0.41 \%$.
\end{abstract}

Keywords: Data Mining, Neive Bayes, Rapidminer, Benefits

\begin{abstract}
Abstrak: Penerapan teknologi informasi saat ini berkembang begitu pesat. Salah satunya penerapan teknologi yang dapat diterapkan didunia industri yaitu untuk evaluasi terhadap kinerja perusahaan. Evaluasi merupakan suatu keharusan bagi perusahaan untuk terus maju dan berkembang menghadapi persaingan usaha. Salah satu cara mengevaluasi yang dapat dugunakan secara objektif yaitu penggalian informasi melalui database yang tersimpan.Penelitian ini bermaksud untuk menganalisa faktor yang mempengaruhi hasil keuntungan berdasarkan data hasil keuntungan. Data tersebut akan dianalisis menggunakan metodeneive bayes. Melalui metode ini akan mendapatkan pola yang mempengaruhi keuntungan.Namun tidaklah mudah dalam menganalisis data dengan metode ini dikarenanakan banyaknya data yang akan menghabiskan biaya dan waktu yang cukup lama. Maka untuk mempermudah analisis tersebut, peneliti menggunakan alat bantu dalam menganalisis data hasil keuntungan yaitusoftware rapidminer.Berdasarkan hasil analisis yang dilakukan, software rapidminer dapat membantu dan mempermudah menghasilkan probabilitas untuk dijadikan prediksi. Hasil penelitian ini adalah dari uji set yang dilakukan, prediksi hasil keuntungan dapat dipastikan tercapai dan kemungkinan kepastian tercapai $0,59 \%$ serta kemungkinan tidak tercapai $0,41 \%$.
\end{abstract}

Kata Kunci : Data Mining, Neive Bayes, Rapidminer, Keuntungan 
DOI: https://doi.org/10.33330/jurteksi.v5i2.365

Available online at http://jurnal.stmikroyal.ac.id/index.php/jurteksi

\section{PENDAHULUAN}

Penerapan teknologi informasi saat ini berkembang begitu pesat. Salah satunya penerapan teknologi yang dapat diterapkan didunia industri yaitu untuk evaluasi terhadap kinerja perusahaan. Evaluasi merupakan suatu keharusan bagi perusahaan untuk terus maju dan berkembang menghadapi persaingan usaha. Salah satu cara mengevaluasi yang dapat dugunakan secara objektif yaitu penggalian informasi melalui database yang tersimpan.

Jumlah data yang begitu besar yang terdapat dalam database mengakibatkan sulitnya untuk mengevaluasi kinerja usaha secara menyeluruh. Maka dari itu dibutuhkan peranan teknologi untuk membantu proses usaha. Seperti yang terjadi pada perusahaan UD. Arif Jaya, perusahaan selalu melakukan evaluasi terhadap hasil penjualannya, namun hanya berdasarkan omset yang didapat saja. Sehingga akan mengalami kekalahan dalam bersaing. Padahal laporan hasil keuntungan bukan hanya faktor omset saja yang terlihat, namun terdapat faktor lainnya seperti pembelian, stok, biaya dan lainnya juga dapat terlihat dalam laporan hasil keuntungan. Selain itu, pengelolaan data yang dilakukan selama ini pun tidak menyeluruh, dikarenakan banyak nya data yang harus dianalisis sehingga memerlukan alat bantu dalam pengelolaannya.

Berdasarkan uraian di atas, maka peneliti memiliki ketertarikan untuk membantu menuntaskan permasalahan tersebut melalui proses penggalian data hasil penjualan. Penggalian data akan dilakukan menggunakan metode neive bayes. Melalui metode ini akan mendapatkan pola atau hubungan yang mempengaruhi terbentuknya hasil keuntungan. Namun tidaklah mudah dalam menganalisis data dengan metode ini dikarenakan banyaknya jumlah data yang akan dianlisis serta menghabiskan biaya dan waktu yang cukup lama. Maka untuk mempermudah analisis tersebut, peneliti menggunakan alat bantu dalam menganalisis data hasil keuntungan yaitu menggunakan software rapidminer.

Naive Bayes adalah pengklasifikasian statistik yang dapat digunakan untuk memprediksi probabilitas keanggotaan suatu class. Naive Bayes didasarkan pada teorema Bayes yang memiliki kemampuan klasifikasi serupa dengan decision tree dan neural network. Naive Bayes terbukti memiliki akurasi dan kecepatan yang tinggi saat diaplikasikan ke dalam database dengan data yang besar [1].

\section{Hasil Keuntungan}

Keuntungan merupakan selisih antara penerimaan dan pengeluaran, sehingga keuntungan jangka pendek dengan menganggap biaya variabel sebagai pengurang [2].

\section{Data Mining}

Data mining dapat diartikan sebagai pengekstrakan informasi baru yang diambil dari bongkahan data besar yang membantu dalam pengambilan keputusan [3].

\section{Naive Bayes}

Algoritma Naive Bayes merupakan salah satu algoritma yang terdapat pada teknik klasifikasi. Naive Bayes merupakan pengklasifikasian dengan metode probabilitas dan statistik yang dikemukan oleh ilmuwan Inggris Thomas Bayes, yaitu memprediksi peluang di masa depan berdasarkan pengalaman dimasa sebelumnya 
sehingga dikenal sebagai Teorema Bayes. Teorema tersebut dikombinasikan dengan Naive dimana diasumsikan kondisi antar atribut saling bebas. Klasifikasi Naive Bayes diasumsikan bahwa ada atau tidak ciri tertentu dari sebuah kelas tidak ada hubungannya dengan ciri dari kelas lainnya [4].

Teorema keputusan Bayes adalah adalah pendekatan statistik yang fundamental dalam pengenalan pola (pattern recoginition). Naive bayes didasarkan pada asumsi penyederhanaan bahwa nilai atribut secara konditional saling bebas jika diberikan nilai output. Dengan kata lain, diberikan nilai output, probabilitas mengamati secara bersama adalah produk dari probabilitas individu [5].

\section{RapidMiner}

RapidMiner adalah platform perangkat lunak data ilmu pengetahuan yang dikembangkan oleh perusahaan dengan nama yang sama, yang menyediakan lingkungan terpadu untuk pembelajaran mesin (machine learning), pembelajaran mendalam (deep learning), penambangan teks (text mining), dan analisis prediktif (predictive analytics). Aplikasi ini digunakan untuk aplikasi bisnis dan komersial serta untuk penelitian, pendidikan, pelatihan, pembuatan prototype dengan cepat, dan pengembangan aplikasi serta mendukung semua langkah proses pembelajaran mesin termasuk persiapan data, visualisasi hasil, validasi dan pengoptimalan. RapidMiner dikembangkan dengan model open core [6].

\section{METODE}

Adapun kerangka kerja dari penelitian ini yaitu sebagai berikut :

1. Mempelajari Literatur

Pada tahap ini peneliti akan mengkaji secara menyeluruh topik yang akan dibahas dalam penelitian baik dari jurnal maupun buku.

2. Pengumpulan Data

Pengumpulan data dilakukan di lokasi penelitian. Data yang dikumpul data yang berasal dari laporan hasil keuntungan dan melakukan proses wawancara sesuai dengan kebutuhan dari penerapan data mining.

3. Menganalisis Data

Data yang telah dikumpulkan akan dianalisis menggunakan alat bantu software rapidminer dengan penerapan metode naive bayes untuk mempermudah proses penelitian.

\section{HASIL DAN PEMBAHASAN}

Berdasarkan hasil dari pengumpulan data yang telah dilakukan, untuk memenuhi dari kebutuhan sistem, maka dilakukan transfomasi data terlebih dahulu yang akan membentuk decission system. decission system ini akan di import ke dalam alat bantu yang telah ditentukan peneliti yaitu menggunakan software rapidminer. Adapun data import yang dimksud yaitu sebagai berikut : 
Vol. V No. 2, Juni 2019, hlm. 199 - 204

DOI: https://doi.org/10.33330/jurteksi.v5i2.365

Available online at http://jurnal.stmikroyal.ac.id/index.php/jurteksi

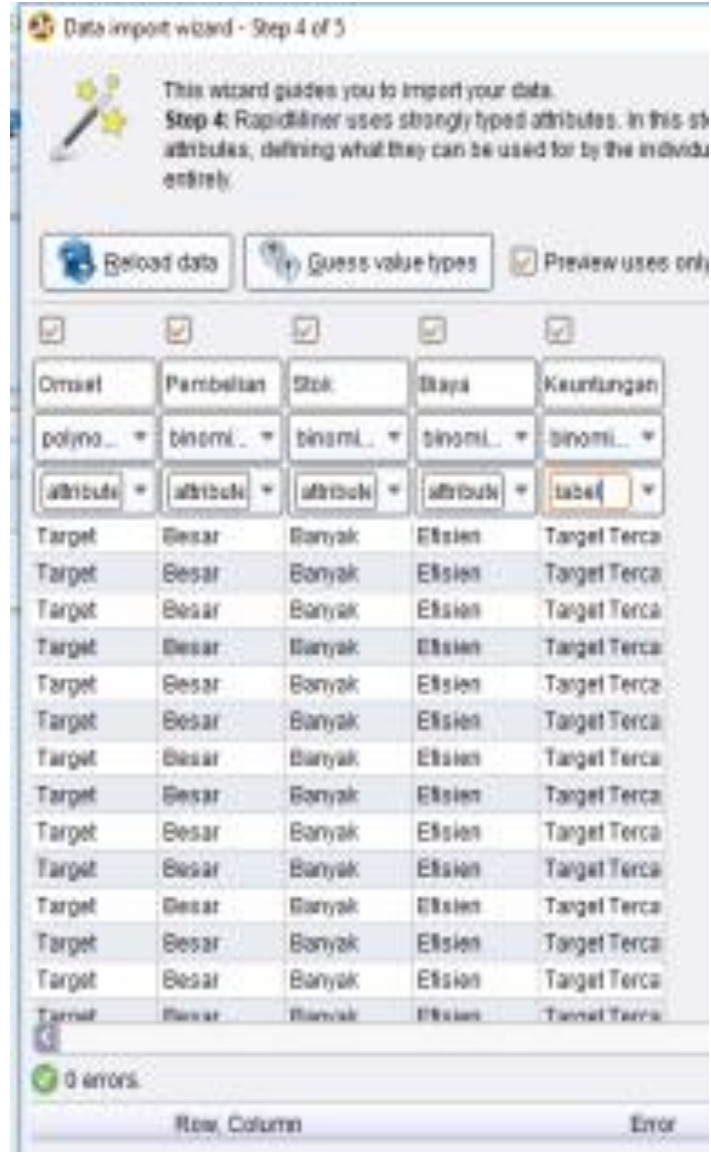

Gambar 1. Data Import Wizard

Pada gambar 1 di atas, dapat terlihat atribut kondisi dari hasil keuntungan yaitu adanya omset, pembelian, stok, dan biaya. Sedangkan atribut keputusan adalah hasil keuntungan yang ditandai dengan adanya tanda label pada form wizard tersebut.

Setelah itu dalam pengaplikasian software rapidminer yaitu akan dilakukan proses pengkoneksian antara data yang telah diimport dengan operator metode naive bayes didalam menu operator. Kemudian men-drag data dan operator tersebut atau melakukan proses pemindahan kedalam jendela process. Maka terlihat koneksi tersebut pada gambar sebagai berikut.

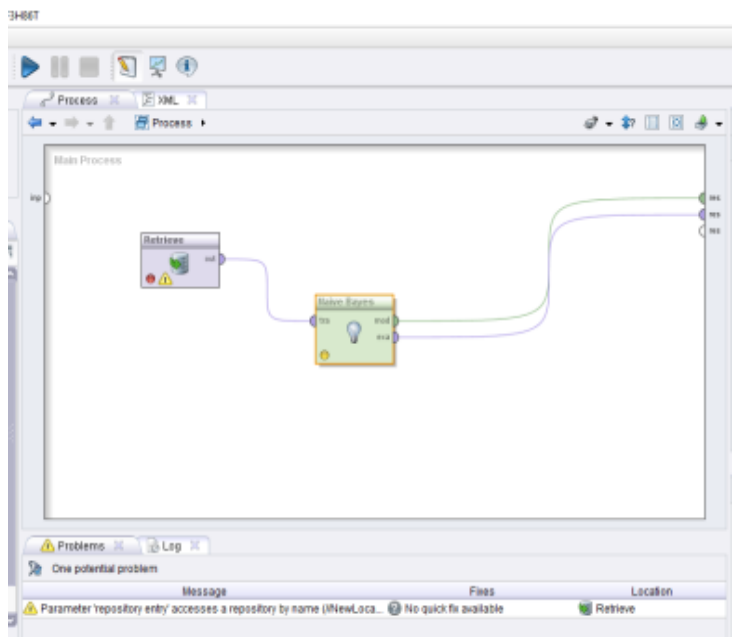

Gambar 2. Koneksi Data Import dengan Metode Naive Bayes

Dari tahapan yang terlihat pada gambar 2, maka selanjutnya akan dilakukan proses menjalankan aplikasi dengan mengklik tombol run pada jendela aplikasi. Sehingga dari hasil proses yang dijalankan mendapatkan hasil yaitu sebuah probabilitas kemunculan setiap nilai dari masingmasing atribut kondisi hasil keuntungan. Hasil probabilitas yang telah diproses dapat terlihat pada gambar berikut ini.

\begin{tabular}{|l|l|l|l|}
\hline & \\
\hline
\end{tabular}

Gambar 3. Nilai Probabilitas 
Gambar 3 di atas merupakan probabilitas kemunculan dari atribut omset, pembelian, stok dan biaya. Setelah mendapatkan probabilitas hasil tersebut, maka selanjutnya akan dilakukan proses test set berikut.

1. Apabila diketahui hasil keuntungan dengan omset target, pembelian nya besar, stok nya banyak, biaya nya efesien. Maka dapat dihitung :

Tercapai $=$

$$
\begin{aligned}
& 0,480 * 0,667 * 0,773 * 0,773 * 0,625 \\
& =0,120
\end{aligned}
$$

Tidak Tercapai $=$

$$
0,222 * 0,489 * 0,489 * 0 * 0,291=0
$$

Nilai probabilitas diatas dapat dihitung melakukan normalisasi terhadap likelihood tersebut sehingga jumlah nilai yang diperoleh $=1$

Probabilitas Tercapai

$=\frac{0,120}{0,120+0}=1$

Probabilitas Tidak Tercapai

$=\frac{0}{0+0,120}=0$

Dari jumlah nilai probabilitas tercapai diatas mendapat jumlah nilai 1 , maka dapat dipastikan target hasil keuntungan pasti tercapai.

2. Apabila diketahui hasil keuntungan dengan omset nya lebih, pembelian nya besar, stok nya sedikit dan biaya nya tidak efesien. Maka dapat dihitung :

Tercapai $=$

$0,413 * 0,667 * 0,227 * 0,227 * 0,625=$ 0,009

Tidak Tercapai $=$ $0 * 0,489 * 0,511 * 1 * 0,291=0$

Nilai probabilitas di atas dapat dihitung melakukan normalisasi terhadap likelihood tersebut sehingga jumlah nilai yang diperoleh $=1$

Probabilitas Tercapai

$=\frac{0,009}{0,009+0}=1$

Probabilitas Tidak Tercapai

$=\frac{0}{0+0,009}=0$

Dari jumlah nilai probabilitas tercapai diatas mendapat jumlah nilai 1 , maka dapat dipastikan target hasil keuntungan pasti tercapai.

3. Apabila diketahui hasil keuntungan dengan omset nya tercapai, pembelian nya sedikit dan biaya tidak efesien. Maka dapat dihitung :

Tercapai $=$ $0,480 * 0,667 * 0,227 * 0,625=0,045$

Tidak Tercapai $=$ $0,222 * 0,489 * 1 * 0,291=0,031$

Nilai probabilitas di atas dapat dihitung melakukan normalisasi terhadap likelihood tersebut sehingga jumlah nilai yang diperoleh $=1$

Probabilitas Tercapai

$=\frac{0,045}{0,045+0,031}=0,592$

Probabilitas Tidak Tercapai

$=\frac{0,031}{0,031+0,045}=0,408$

Dari jumlah nilai probabilitas tercapai diatas mendapat jumlah nilai tercapai 0,592 dan tidak tercapai 0,408 , maka kemungkinan kepastian tercapai $0,59 \%$ dan kemungkinan tidak tercapai $0,41 \%$.

\section{UCAPAN TERIMA KASIH}

Ucapan terima kepada DRPM Direktorat Jenderal Penguatan Riset dan Pengembangan Kementerian Riset, Teknologi dan Pendidikan Tinggi 
DOI: https://doi.org/10.33330/jurteksi.v5i2.365

Available online at http://jurnal.stmikroyal.ac.id/index.php/jurteksi

Sesuai dengan Kontrak Penelitian Tahun Anggaran 2019.

\section{SIMPULAN}

Adapun kesimpulan yang dapat diambil dari penelitian ini adalah :

1. Dalam menganalis data hasil keuntungan menggunakan alat bantu software rapidminer dapat mempermudah pengelolaan data perusahaan melalui analisis data hasil keuntungan yang besar sehingga lebih cepat dan lebih efesien.

2. Berdasarkan hasil analisis yang telah dilakukan, maka hasil dari test set yang telah diprediksi ada yang mendapatkan kepastian tercapai dan juga kemungkinan kepastian tercapai $0,59 \%$ dan kemungkinan tidak tercapai $0,41 \%$.

\section{DAFTAR PUSTAKA}

[1] Nugroho, Y. S. (2014). Data Mining Menggunakan Algoritma Naive Bayes Untuk Klasifikasi Kelulusan Mahasiswa Universitas Dian Nuswantoro. Dian Nuswantoro Fakultas Ilmu Komputer Skripsi.

[2] Sembiring, M. A., \& Manurung, N. (2018, September). Integrasi Software Rosetta Dalam Menganalisa Keuntungan Menggunakan Metode Rough Set. In Seminar Nasional Royal (SENAR) (Vol. 1, No. 1, pp. 2932).

[3] Sembiring, M. A. (2016). Penerapan metode decission tree algoritma c45 untuk memprediksi hasil belajar mahasiswa berdasarkan riwayat akademik. JURTEKSI ROYAL Vol 3 No 1, 3.

[4] Bustami, B. (2013). Penerapan Algoritma Naïve Bayes Untuk Mengklasifikasi Data Nasabah Asuransi. TECHSI-Jurnal Teknik Informatika, 5(2).

[5] Ridwan, M., Suyono, H., \& Sarosa, M. (2013). Penerapan Data Mining Untuk Evaluasi Kinerja Akademik Mahasiswa Menggunakan Algoritma Naive Bayes Classifier. jurnal EECCIS, 7(1), 59-64.

[6] Rizqifaluthi, H., \& Yaqin, M. A. (2019). Process Mining Akademik Sekolah menggunakan RapidMiner. MATICS, 10(2), 4751. 